\title{
KONSEP KHOLIFATULLAH SEBAGAI MODEL IDEAL KEPEMIMPINAN ORGANISASI SOSIAL
}

\author{
Fathor Rachman \\ INSTIKA Sumenep \\ Email: efrachman81@gmail.com
}

\begin{abstract}
Example and belief is certainly more devastating impact than on the energy crisis, food, health, transport and water. Because, this is testament to the confidence crisis will be the absence of visionary leaders, competent, and have integrity as well as credible. This is precisely the leadership crisis will exacerbate the nation of Indonesia next and will cause an energy crisis, health, food, even the quality of education any join plummeted, politics and so on will be more severe.

In this regard according to Quran conception of man is also often referred to as the Caliph in the sense of power (mandataris, not ruler). In the status that is associated with a variety of human rights, obligations, and responsibilities, all of which constitute the mandate for him. The khalifatullah concept was mentioned explicitly in the Qur'an is a reflection for man how to become leader of the trustful, intelligent, creative, callous, have integrity and are responsible for enforcing all the rules of law and made all the potential and of the natural and human resources as the power to lead.

This concept will be examined in this article, how the spirit and values contained in the concept of the khalifatullah it could grow, evolve, and be the spirit of a leadership organization, be it a religious organizations, educational organizations, the political organization, the Organization of regional device (OPD)/dinas, the Organization of the company, as well as State organizations.
\end{abstract}

Keyword: The Leadhership, khilafah, kholifah, ideal.

\section{Pendahuluan}

Krisis keteladanan dan kepercayaan yang telah melanda hampir semua lapisan masyarakat merupakan salah satu indikasi dari lemahnya kepemimpinan nasional. Krisis ekonomi dan politik yang terjadi sejak tahun 1997 merupakan titik awal dari terjadinya krisis pada semua aspek kehidupan bangsa Indonesia, yang kemudian merambah pada krisis kepemimpinan yang membuat lahirnya krisis kedisiplinan, keteladanan, dan kepercayaan.

Krisis keteladanan dan kepercayaan tentu lebih dahsyat dampaknya dari pada krisis energi, kesehatan, pangan, transportasi dan air. Sebab, krisis kepercayaan ini merupakan bukti akan tidak adanya pemimpin yang visioner, 
kompeten, dan memiliki integritas ${ }^{1}$ serta kredibelitas. Krisis kepemimpinan inilah yang justru akan memperparah situasi bangsa Indonesia berikutnya dan akan menyebabkan krisis energi, kesehatan, pangan, pendidikan, politik dan sebagainya akan semakin parah.

Faktanya, semakin hari biaya kesehatan semakin sulit terjangkau, keadilan hukum semakin sulit didapat,biaya pendidikan semakin mahal, bahkan semakin banyak rakyat yang mengalami kemiskinan dan sebagainya yang sampai sekarang belum ditemukan solusinya. Inilah sebagian kecil permasalahan akibat dari krisis kepemimpinan dengan segala aspek yang ditimbulkannya.

Salah satu contoh yang menarik dicermati adalah masalah korupsi. Jika dahulu korupsi sangat sulit terdeteksi karena prakteknya tersentralisasi dari pusat, kini telah menyebar pada semua lapisan masyarakat dari tingkat RT/RW hingga tingkat lembaga kementerian dan kepresidenan. Anehnya, praktek korupsi itu dilakukan dengan terang-terangan dan sangat mudah terdeteksi, meskipun kadang-kadang sulit dibuktikan di mata hukum (pengadilan).

Kondisi ini semakin membuktikan betapa bahayanya krisis kepercayaan jika dibiarkan berlarut-larut. Di sinilah bangsa Indonesia dan masyarakat sedang membutuhkan suri tauladan yang tinggi dari para pemimpin untuk mengembalikan kepercayaan masyarakat. Lahirnya pemimpin yang kredibel, visioner, kompeten, memiliki integritas dan mau berbuat yang lebih banyak untuk kepentingan bangsa, merupakan harapan masyarakat. Sebuah model kepemimpinan yang mampu memberikan dorongan dan suri tauladan yang sesuai dengan tugas dan wewenangnya sebagai pemimpin. Leadership is an action, not a position, kepemimpinan adalah sebuah tindakan (kinerja), bukan berkaitan dengan posisi (kekuasaan). Karena itu, siapapun diri kita dan apapun jabatannya adalah pemimpin. Minimal memimpin diri kira sendiri, dan maksimal mampu menjadi pemimpin yang bisa memberikan pelayanan (servant leadership) yang terbaik bagi masa depan bangsa Indonesia dan umat manusia secara keseluruhan.

Indonesia sangat merindukan suri teladan leadership yang meyakini bahwa jabatan adalah tanggung jawab dunia akhirat dan bukan sebuah kemegahan, apalagi hanya untuk menambah kekayaan semata dengan berbagai caranya. Pemimpin yang tidak bisa tidur nyenyak karena masih banyak rakyatnya yang kelaparan, tidak punya tempat tinggal dan hidup dalam kondisi yang memprihatinkan. Pemimpin yang tidak terlalu nikmat duduk dalam ruangan berAC, sementara rakyatnya masih banyak yang menjadi korban longsor, lumpur dan banjir ${ }^{2}$.

\footnotetext{
${ }^{1}$ Muhammad Syafii Antonio, Teladan Sukses dalam Hidup dan Bisnis: Mubammad SAW, The Super Leader, Super Manager, (Jakarta: Tazkia Multimedia \& ProLM Centre, 2007), hal. 3

${ }^{2}$ Ibid, hal. 6
} 
Dalam sejarah, kepemimpinan seperti di atas telah dicontohkan dengan sangat sempurna oleh Nabi Muhammad Saw. Dengan integritasnya yang luar biasa sehingga mendapatkan gelar al-amin (terpercaya), Nabi Muhammad Saw mampu mengembangkan kepemimpinan yang paling ideal dan paling sukses dalam sejarah peradaban umat manusia. ${ }^{3}$. Sifat-sifatnya yang utama yaitu siddiq (integrity), amanah (trust), fathanah (smart) dan tabligh (openly) mampu mempengaruhi orang lain dengan cara mengilhami, memotivasi tanpa mengindoktrinasi, menyadarkan tanpa menyakiti, membangkitkan tanpa memaksa dan mengajak tanpa memerintah. Itulah hakikat yang esensial tentang kepemimpinan.

Bahkan, hampir semua teori kepemimpinan modern yang banyak berkembangan belakangan ini, sesungguhnya telah dilakukan dan dipraktekkan dengan sempurna oleh Nabi Muhammad SAW, sehingga dia disebut sebagai the super leader dan super manager. Misalnya, dapat dibuktikan dari empat fungsi kepemimpinan yang dikemukakan oleh Stephen R. Covey, bahwa pemimpin harus memiliki fungsi sebagai perintis (pathfinding), penyelaras (aligning), pemberdaya (empowering), dan panutan (modeling) $)^{5}$. Keempat fungsi ini juga telah dibuktikan oleh Nabi dengan sangat jelas dari beberapa literatur yang mengkaji tentang betapa sempurnanya praktek kepemimpinan yang telah dilakukan oleh Nabi Muhammad.

Tentu saja, kepemimpinan yang dikembangkan oleh Nabi adalah sebuah konsep leadership yang sering disebut dalam beberapa literatur sebagai prophetic leadership (kepemimpinan kenabian).Sebuah kepemimpinan yang bersumber dari nilai-nilai Al-Quran, yang telah mengamanatkan umat manusia untuk menjadi khalifabtullah (wakil Allah) di muka bumi agar ia menjalankan amanah Allah yaitu dengan menegakkan aturan-aturan-Nya, menampakkan kejaiban karya-Nya, rahasia-rahasia ciptaan-Nya, keindahan-keindahan hikmah-Nya serta manfaatmanfaat hukum-Nya untuk kepentingan manusia secara universal.

Dalam kaitan ini menurut konsepsi Al-Quran manusia juga sering disebut sebagai khalifah dalam pengertian kuasa (mandataris, bukan penguasa). Dalam status itulah manusia terkait dengan berbagai hak, kewajiban, serta tanggung jawab, yang semuanya merupakan amanah baginya. Konsep khalifatullah yang telah disebutkan secara eksplisit dalam Al-Quran merupakan cerminan bagi manusia bagaimana menjadi pemimpin yang amanah, cerdas, kreatif, berperasaan, memiliki integritas dan bertanggung jawab untuk menegakkan

\footnotetext{
${ }^{3}$ Michael H. Hart. Seratus Tokoh yang Paling Berpengaruh dalam Sejarah. (Jakarta: Pustaka Jaya, 1994), Hal. 27.

${ }^{4}$ Muhammad Syafii Antonio, Teladan Sukses dalam Hidup dan Bisnis: Muhammad SAW, ...., hal. 19

${ }^{5}$ Stephen R. Covey, the $8^{\text {th }}$ Habit from Effectiveness to Greaness, (London: Simon \& Schuster Uk Ltd), p. 114
} 
segala aturan hukum dan menjadikan segala potensi dan sumber daya manusia dan alam sebagai kekuatan untuk memimpin.

Konsep inilah yang akan dikaji dalam artikel ini, yaitu bagaimana spirit dan nilai-nilai yang terkandung dalam konsep khalifatullah itu bisa tumbuh, berkembang, dan menjadi roh sebuah kepemimpinan organisasi, baik itu organisasi agama, organisasi pendidikan, organisasi politik, organisasi perusahaan, maupun organisasi Negara.

\section{Khalifatullah Sebagai Konsep Kepemimpinan}

\section{Pengertian Khalifatullah}

Kata khalifah berasal dari kata kholafa - yakblifu - khalfan - kbilafatan yang berarti menggantikan, menempati tempatnya ${ }^{6}$. Nurcholis Madjid mengartikan khalifah dengan yang mengikuti dari belakang, jadi wakil atau pengganti di bumi. ${ }^{7}$ Sedangkan menurut M. Quraish Shihab kata khalifah, berakar dari kata khulafa' yang pada mulanya berarti belakang, kemudian seringkali diartikan sebagai pengganti. Karena yang menggantikan selalu berada atau datang di belakang, sesudah yang digantikannya. ${ }^{8}$

Hasan Langgulung membagi pengertian khalifah berdasarkan siapa menggantikan siapa dalam kata khalifah menjadi tiga pendapat. Pertama, bahwa umat manusia sebagai makhluk yang menggantikan makhluk yang lain yang telah menepati bumi ini. Kedua, khalifah hanya bermakna kumpulan manusia menggantikan yang lain. Ketiga, Khalifah tidak sekadar seorang menggantikan orang lain, tapi ia (manusia) adalah pengganti Allah. Allah datang dulu, khalifah bertindak dan berbuat sesuai dengan perintah Allah.'

M. Quraish Shihab memberikan sebuah kongklusi, bahwa khalifah adalah seseorang yang diberi kedudukan oleh Allah untuk mengelola suatu wilayah, khalifah berkewajiban untuk menciptakan suatu masyarakat yang hubungannya dengan Allah baik, kehidupan masyarakatnya harmonis dan agama, akal, dan budayanya terpelihara. ${ }^{10}$ Penjelasan lain mengartikan bahwa khalifatullah sebagai penerjemah segala sifat-sifat Allah SWT dalam kehidupan dan penghidupan manusia, serta dalam batas-batas kemanusiaan. ${ }^{11}$

\footnotetext{
${ }^{6}$ Ahmad Warson Munawwir, Al munawwir, Kamus Arab - Indonesia, (Yogyakarta:) hlm. 390 - 391

${ }^{7}$ Nurcholis Madjid, Islam, Doktrin dan Peradaban (Jakarta: Paramadina, 1992), hlm. 8

${ }^{8}$ M. Quraish Shihab, Membumikan Al- Quran, Fungsi dan Peran Wabyu dalam Kebidupan Masyarakat, cet. XXII (Bandung: Mizan, 2001), hlm.157.

9 Hasan Langgulung, Manusia dan Pendidikan, Suatu Analisa Psikologi dan Pendidikan (Jakarta: Pustaka Al Husna, 1989), hlm. 75

${ }^{10}$ Ibid. hlm.166

11 Endang Saifuddin Anshari, Wawasan Islam, Pokok-Pokok Pikiran tentang Islam dan Umatnya (Bandung: Pustaka, 1983), hlm. 121
} 
Dari beberapa pengertian di atas, jelas sekali bahwa makna khalifah merupakan konsep tentang peran manusia sebagai khalifatullah di muka Bumi. Ini berarti Allah dengan sendirinya mempercayai manusia untuk menjadi perencana, pengelola, pengatur, sekaligus pengawas seluruh kehidupan di muka bumi. Ini berarti konsep khalifatullah itu sesungguhnya sebuah konsep leadership yang memiliki arti yang sangat luas yang mencakup tentang peran manusia sebagai pengganti Allah untuk mengelola dan memimpin seluruh aspek kehidupan di muka bumi, termasuk kehidupan umat manusia dalam suatu komunitas (organisasi).

\section{Eksistensi Manusia dalam Konsep Khalifatullah}

Manusia mempunyai keistimewaan dibanding dengan makhluk Tuhan yang lainnya di muka bumi ini. Keistimewaan ini bisa dilihat dari sisi penciptaan fisik maupun personalitas karakternya. Karena keistimewaannya itu, manusia memiliki tugas dan kewajiban yang berbeda dengan makhluk yang lain ${ }^{12}$. Hal ini dapat kita lihat dalam surat Al-Baqarah ayat 30-33 yang memaparkan proses kejadian manusia dan pengangkatannya sebagai khalifah.Proses kejadian inilah yang dapat memberikan pengertian kedudukan manusia sebagai khalifatullah dalam alam semesta.

M. Rasyid Ridla menjelaskan bahwa Q.S. Al-Baqarah ayat 30-33: merupakan kehendak Allah untuk menjadikan khalifah di bumi, yaitu Adam (dan keturunannya) yang telah dilengkapi dengan berbagai potensi. Dijadikannya Adam sebagai khalifah di bumi adalah agar ia menjalankan amanah Allah yaitu dengan menegakkan aturan-aturan-Nya, menampakkan kejaiban karya-Nya, rahasia-rahasia ciptaan-Nya, keindahan-keindahan hikmah-Nya serta manfaat-manfaat hukum-Nya.

Selanjutnya M. Rasyid Ridha menjelaskan bahwa manusia bersamaan dengan kebodohan dan kelemahannya, ia telah diberi kekuatan lain yang disebut "akal". Dengan kekuatan ini manusia menjadi makhluk yang memiliki kehendak dan kebebasan untuk berbuat. Hal itu menunjukkan bahwa manusia adalah makhluk yang kreatif. Telah banyak penemuan ilmiah atau rahasia-rahasia alam yang telah diungkap oleh manusia yang kemudian melahirkan ilmu pengetahuan dan teknologi yang semakin canggih. Hal itu merupakan bukti potensi kreatif yang dimiliki manusia ${ }^{13}$.

Dengan kemampuan yang ia miliki ia dapat mengungkapkan kejaibankejaiban ciptaan Allah dan rahasia-rahasia makhluknya. Al-Maraghi menambahkan, dalam ayat di atas memberikan gambaran bahwa Allah telah melebihkan manusia dari makhluk yang lain. Karena pada diri manusia telah

${ }_{12}$ Tedi Priatna, Reaktualisasi Paradigma Pendidikan Islam (Bandung: Pustaka Bani Quraisy, 2004), hlm. 89

${ }^{13}$ M. Rasyid Ridha, Tafsir Al-Manar (Beirut-Libanon, tth), hlm. 254-264 
disediakan "alat" yang dengannya manusia bisa meraih kematangan secara sempurna di bidang ilmu pengetahuan, lebih jauh jangkauannya dibanding makhluk lain termasuk malaikat. Berdasarkan inilah manusia lebih diutamakan menjadi khalifah di bumi dibanding malaikat. ${ }^{14}$

Manusia dipilih sebagai khalifatullah, sebagaimana diuraikan di atas, karena kelebihan yang dianugerahkan Allah kepada manusia berupa ilmu pengetahuan, yang tidak diberikan kepada makhluk Allah yang lain termasuk malaikat. Hal ini mengindikasikan bahwa untuk dapat menjalankan fungsi dan perannya sebagai khalifah, diperlukan modal atau syarat yaitu ilmu pengetahuan. Hal ini senada dengan pendapat Quraish Shihab bahwa pengetahuan atau potensi yang berupa kemampuan menyebutkan namanama itu merupakan syarat sekaligus modal bagi Adam (manusia) untuk mengelola bumi ini.

Dalam hal ini manusia diberi kemampuan untuk memberikan namanama benda, yakni membentuk konsep-konsep tentang benda-benda itu. Membentuk konsep berarti menguasainya. Jadi sifat pengetahuan manusia adalah konseptual. Berinisiatif menurutnya juga berarti bahwa manusia disamping memiliki potensi merusak ia juga memiliki potensi untuk berbuat baik. Menurutnya ini menunjukkan sifat kreatif manusia. Potensi kreatif ini hanya dianugerahkan kepada manusia, dan tidak kepada malaikat maupun makhluk yang lain. Menurut Machasin, Adam atau manusia yang mempunyai kemampuan untuk berbuat patuh dan durhaka, di dalamnya terkandung unsur kreativitas. ${ }^{15}$

Senada dengan pendapat di atas, Abdur Rahman Shalih Abdullah menyatakan bahwa kemampuan manusia menyebutkan nama-nama dapat diartikan sebagai kemampuan merumuskan konsep. Dalam penjelasan selanjutnya, ia menuturkan bahwa rumusan konsep memiliki dua faedah. Pertama, ia memberikan fasilitas berpikir. Menurutnya konsep memungkinkan manusia melakukan analisa dan sintesa terhadap apa yang dipikirkan. Berbeda dengan binatang maka manusia memiliki kemampuan merumuskan pengetahuan konseptualnya ketika menghadapi permasalahan. Faedah kedua dari pengetahuan konseptual adalah bahwa ia memungkinkan manusia ingat terhadap peristiwa-peristiwa lampau. Manusia mencatat sejarahnya, kemampuan untuk membaca sejarah menjadikan manusia mempunyai kemampuan tertinggi pada aspek-aspek tertentu. Binatang tidak dapat mengingat peristiwa-peristiwa yang pernah dialaminya. Tidak mengherankan, Al-Quran menganggap sejarah sebagai ayat-ayat-Nya, yang

${ }^{14}$ Musthofa Al-Maraghi, Tafsi ${ }^{\wedge} r$ Al-Mara ${ }^{\wedge} g{ }^{\wedge} i$ (terj.) (Semarang: Toha Putra, 1985), hlm. 130-144

${ }^{15}$ Machasin, Menyelami Kebebasan Manusia (Yogyakarta: INHIS-Pustaka Pelajar, 1996), hlm. 8-10 
merangsang praktek berpikir. Kenyataan-kenyataan sejarah tidak disebut sebagai memorisasi, namun kontemplasi. ${ }^{16}$

Kemampuan manusia untuk menemukan bentuk pengetahuan baru dan memecahkan situasi-situasi atau masalah-masalah baru menjadikan manusia mempunyai nilai lebih dari binatang. Perbedaan pengetahuan manusia dari pengetahuan binatang adalah kualitatif, dan bukan kuantitatif. Menurut Abdur Rahman jaringan besar gagasan manusia hanya mungkin diterangkan dalam kemampuannya memberi nama-nama yang dilimpahkan kepada Adam As. Hal ini nyata sekali bahwa gagasan yang dicapai dan konsep-konsep yang dicapai tidak dapat dipisahkan dari peran yang dimainkan yaitu khalifah. ${ }^{17}$ Sehubungan dengan penjelasan di atas, Jalaludin menambahkan bahwa potensi akal yang hanya dianugerahkan Allah kepada manusia, memberi kemampuan kepadanya untuk memahami simbol-simbol, hal-hal yang abstrak, menganalisa dan membandingkan maupun membuat kesimpulan serta memilih dan memisahkan antara yang benar dari yang salah. Kemampuan akal mendorong manusia berkreasi dan berinovasi dalam menciptakan kebudayaan dan peradaban. Manusia dengan kemampuan akalnya mampu menguasai ilmu pengetahuan dan teknologi, mengubah serta merekayasa lingkungannya, menuju situasi kehidupan yang lebih baik, aman dan nyaman. ${ }^{18}$ Semua itu tentunya dalam kerangka menjalankan fungsi dan peran kekhalifahannya (peran kepemimpinannya).

\section{Konsep Khalifatullah Sebagai Cermin Kepemimpinan Manusia}

Dalam beberapa ayat juga disebutkan bahwa manusia memiliki kehidupan ideal, yang dari kehidupan ideal itulah manusia didorong kepada kehidupan riil agar ia dapat teruji sebagai makhluk fungsional ${ }^{19}$. Maksudnya, hidup atau kehidupan riil adalah hidup di bumi sekaligus mati di bumi. Dalam kaitan ini menurut konsepsi Al-Qur'an manusia juga sering disebut sebagai khalifah dalam pengertian kuasa (mandataris, bukan penguasa). Dalam status itulah manusia terkait dengan berbagai hak, kewajiban, serta tanggung jawab, yang semuanya merupakan amanah baginya.

Kemuliaan manusia ini menunjukkan bahwa manusia dibanding dengan makhluk lain memiliki keistimewaan yang membawanya kepada kedudukan yang istimewa pula, yaitu sebagai khalifah (pemimpin). Dalam kedudukan ini manusia diberi peran untuk membangun dan mengembangkan dunia baik secara sendiri-sendiri (individualistik) maupun

16 Abdur Rahman Shalih Abdullah, Landasan dan Tujuan Pendidikan menurut Al-Quran serta Implementasinya (Bandung: Diponegoro, 1991), hlm. 132-133

${ }^{17}$ Ibid., hlm.134

${ }^{18}$ Jalaludin, Teologi Pendidikaan (Jakarta: Raja Grafindo Persada, 2000), hlm. 46

${ }^{19}$ Q.S. Al-Mulk: 2 
bersama-sama (sosial) misalnya dalam wujud mendirikan suatu organisasi ataupun kelompok-kelolompok sosial lainnya. Manusia mampu berperan menentukan nasib mereka sendiri. Peran ini dilakukan secara sadar dan melalui kehendak bebasnya, artinya manusia dapat menentukan masa depannya atas dasar pengetahuannya tentang diri, kehidupan di sekeliling mereka dan berdasarkan intelektualitas serta pemeliharaan diri secara baik.

Lingkup tindakan manusia dalam mewujudkan peran itu mencakup tiga karakteristik yang ada dalam sifat manusia. Pertama, keluasan wawasan dan kesadaran manusia. Manusia mampu mengembangkan cakupan wawasannya melalui perangkat pegetahuannya mereka mampu mempelajari hukum-hukum dan peraturan alam, sehingga memungkinkan mereka menempatkan alam semesta dan kehidupan manusia pada suatu perangkat yang lebih tinggi. Kedua, memiliki keluasan wilayah yang dapat dicakup oleh kehendak manusia. Ketiga, kemampuan inheren untuk membentuk diri adalah milik ekslusif manusia, tidak ada mahkluk lain yang menyandang kemampuan ini. Dengan demikian, hanya manusia sajalah yang melalui hukum-hukum penciptaan, dikaruniai kemampuan menyusun pedoman bagi dirinya dan kelompok sosialnya, untuk mencapai masa depan seperti yang mereka kehendaki. ${ }^{20}$

Menurut Hasan Langgulung, selaku khalifah manusia mempunyai beberapa karakteristik, yaitu:

a. Sejak awal penciptaannya, manusia adalah baik secara fitrah. Ia tidak mewarisi dosa karena Adam meninggalkan surge;.

b. Interaksi antara badan dan ruh menghasilkan khalifah. Karakteristik ini yang membedakan manusia dengan makhluk yang lain;

c. Manusia selaku khalifah memiliki kebebasan berkehendak, suatu kebebasan yang menyebabkan manusia dapat memilih tingkah lakunya sendiri; dan

d. Manusia dibekali akal, dengan akal itu manusia mampu membuat pilihan antara yang benar dan yang salah. ${ }^{21}$

Berbeda dengan M. Quraish Shihab ${ }^{22}$ yang mengharuskan konsep khalifatullah memiliki karakter sebagai manusia secara pribadi maupun kelompok, mampu menjalankan fungsinya sebagai hamba Allah, guna membangun dunia dan sekitarnya sesuai dengan konsep yang ditetapkan Allah. Sehingga khalifatullah harus memiliki empat sisi karakter yang saling terkait. Keempat sisi tersebut adalah:

1) Memenuhi tugas yang diberikan Allah;

${ }^{20}$ Ali Yafie, Teologi Sosial: Telaah Kritis Persoalan Agama dan Kemanusiaan (Yogyakarta: LKPSM, 1997), hlm. 137-139

${ }^{21} \mathrm{Ibid}, \mathrm{hlm} .34-35$.

${ }^{22}$ Ibid hal 257 
2) Menerima tugas tersebut dan melaksanakannya dalam kehiduan perorangan, maupun kelompok (organisasi);

3) Memelihara serta mengelola lingkungan hidup untuk kemanfaatan bersama;

4) Menjadikan tugas-tugas khalifah sebagai pedoman pelaksanaannya.

Konsep inilah yang memberikan makna bahwa manusia dilahirkan dengan segala potensi yang dimilikinya seharusnya digunakan untuk menjadikan potensinya sebagai pemimpin bagi kehidupan dirinya sendiri, termasuk juga pemimpin bagi lingkungan sekitarnya baik secara perorangan maupun kelompok. Amanah Allah Swt yang diberikan kepada manusia merupakan bukti kepercayaan Allah Swt kepada manusia agar bisa menjadi wakil-Nya di muka bumi untuk mengelola dan mengatur kehidupan bumi dan segala isinya.

Melalui amanah inilah, manusia dituntut untuk bisa menjadi khalifah (pemimpin) yang dapat memberikan dampak yang positif terhadap lingkungan sekitarnya, melalui segala potensi yang telah dianugerahkan oleh Allah Swt. Melalui potensi itulah, manusia sebisa mungkin harus berkompetisi menjadi yang terbaik di antara sesamanya. Sebab, dengan potensinya manusia dengan sendirinya dapat menentukan sendiri kualitasnya di hadapan manusia yang lain. Perbedaan kualitas antara satu orang dengan orang lain inilah yang menjadikan manusia yang satu lebih dipercaya dan lebih dihargai dari yang lainnya. Membangun kepercayaan itulah yang kemudian menyebabkan seseorang bisa dipercaya untuk dijadikan pemimpin.

\section{Konsep Kepemimpinan dalam Organisasi}

\section{Pengertian Kepemimpinan}

Pengertian tentang kepemimpinan tidak terhitung jumlahnya. Sebab dalam kegiatan menajemen, kepemimpinan hampir tidak bisa dilepaskan dengan manajemen. Term kepemimpinan dan manajemen kadang-kadang digunakan secara bergantian atau dianggap sinonim, bahkan ada yang mengatakan kepemimpinan merupakan pelengkap dari kegiatan manajemen. Namun demikian, perbedaan yang digambarkan antara kedua konsep tersebut dapat diperjelas oleh pernyataannya Bush \& Coleman yang mengatakan bahwa; "leadership is sometimes linked to vision and values while management is said to relate to processes and structures". Kepemimpinan berhubungan dengan visi dan nilai, sedangkan manajemen berhubungan dengan proses dan struktur ${ }^{23}$.

\footnotetext{
${ }^{23}$ Bush, T. \& Coleman, M. (2000). Leadership and strategic management in education. (London: Paul Chapman Publisihing Ltd., 2000), p. 4
} 
Pengertian tentang kepemimpinan dirumuskan secara beragam oleh para pakar manajemen sesuai dengan luas dan sempitnya aktivitas manajemen yang dilakukan oleh seseorang. Seperti Peter Blockyang mendefinisikan kepemimpinan dengan rumusan; "leadership is persuading others to sublimate their own self interests and adopt the goals of a group as their own'124. Kepemimpinan merupakan proses mengajak orang lain untuk memenuhi kepentingan mereka sendiri dan untuk mencapai tujuan suatu kelompok sesuai kepentingan mereka. Sedangkan Truman mendefinisikan pemimpinan dengan rumusan yang sederhana. Ia mengatakan bahwa; "leadership is the ability to get men to do what they don't like to do and like it"25. Kepemimpinan adalah kemampuan untuk mempengaruhi orang lain agar mereka melakukan sesuatu yang disukai ataupun yang tidak disukai.

Kepemimpinan sebagai salah satu fungsi manajemen merupakan hal yang sangat penting untuk mencapai tujuan organisasi. Dengan kepemimpinan seseorang dituntut untuk menghadapi berbagai macam aspek yang ada dalam organisasi seperti struktur atau tatanan, koalisi, kekuasaan, dan kondisi lingkungan organisasi. Sebaliknya kepemimpinan rasanya dapat dengan mudah menjadi penyelesaian yang luar biasa terhadap persoalan apa saja yang sedang menimpa suatu organisasi. ${ }^{26}$

Dalam hal ini kepemimpinan dapat berperan di dalam melindungi beberapa isu pengaturan organisasi yang tidak tepat, seperti: distribusi kekuasaan yang menjadi penghalang tindakan yang tidak efektif, kekurangan berbagai macam sumber, prosedur yang dianggap buruk dan sebagainya, yaitu problem-problem organisasi yang lebih bersifat mendasar. ${ }^{27}$ Begitu banyaknya definisi tentang kepemimpinan, menurut Bass dan Stogdill sebagaimana yang dikutip oleh Husaini Usman, terdapat 3000 lebih penelitian dan definisi kepemimpinan yang telah diciptakan manusia. ${ }^{28}$

Secara etimologi, kepemimpinan menurut Inu Kencana Syafi'e, dapat diartikan sebagai berikut:

1) Berasal dari kata "pimpin" (dalam Bahasa Inggris “lead") berarti bimbing atau tuntun. Dengan demikian di dalamnya ada dua pihak yaitu yang dipimpin (umat) dan yang memimpin (imam);

2) Setelah ditambah awalan "pe" menjadi "pemimpin" (dalam bahasa Inggris "leader") berarti orang yang mempengaruhi orang lain melalui

\footnotetext{
${ }^{24}$ Lunenburg, F.C. \& Ornstein, A.C. (2000). Educational administration concepts and practices. (3 $\left.3^{\text {rd }} . e d.\right)$ (Belmont: Wadsworth Thomsong Learning, 2000), p. 113

${ }^{25}$ Sadler, P. (1997). Leadership. (The fast-track MBA series). (London: Kogan Page Limited, 1997), p. 21

${ }^{26}$ Wahjosumidjo, Kepemimpinan Kepala Sekolah (Jakarta: PT Rajagrafika Persada, 2002), hlm. 15

${ }^{27}$ Ibid, hlm. 15

${ }^{28}$ Husaini Usman, Manajemen, Teori, Praktik, dan Riset Pendidikan (Jakarta: PT Bumi Aksara, 2006), hlm. 250
} 
proses kewibawaan komunikasi sehingga orang lain tersebut bertindak untuk mencapai tujuan tertentu;

3) Apabila ditambah akhiran "an" menjadi "pimpinan" artinya orang yang mengepalai. Antara pemimpin dengan pimpinan dapat dibedakan, yaitu pimpinan (kepala) cenderung lebih sentralistis, sedangkan pemimpin lebih demokratis.

4) Setelah dilengkapi dengan awalan "ke" menjadi "kepemimpinan" (dalam bahasa Inggris "leadership") berarti kemampuan dan kepribadian seseorang dalam mempengaruhi serta membujuk pihak lain agar melakukan tindakan pencapaian tujuan bersama, sehingga dengan demikian yang bersangkutan menjadi awal struktur dan pusat proses kelompok. ${ }^{29}$

Secara terminologi terdapat beberapa definisi tentang kepemimpinan. Seseorang pemimpin, baik ia merupakan pemimpin formal maupun informal menjalankan atau melaksanakan "kepemimpinan" yang dengan sendirinya berbeda: derajatnya, bobotnya, daerah jangkauannya dan sasaransasarannya. ${ }^{30}$. Pemimpin adalah orang yang dianut oleh orang-orang lain dalam mencapai tujuan bersama. Dengan demikian dia mempunyai wibawa, kekuasaan, ataupun pengaruh. ${ }^{31}$

Agar diperoleh gambaran mengenai keragamaan definisi kepemimpinan, berikut ini akan disajikan beberapa definisi yang dikutip oleh Soebagio Atmodiwirio dan Soeranto Totosiswanto sebagai berikut:

1) Kepemimpinan adalah kemampuan untuk mempengaruhi pihak lain berbuat sesuai dengan kehendak orang itu, meskipun pihak lain itu tidak menghendakinya.

2) Kepemimpinan adalah suatu kegiatan untuk mempengaruhi perilaku orang-orang agar bekerjasama menuju kepada suatu tujuan tertentu yang mereka inginkan bersama.

3) Kepemimpinan adalah suatu proses mempengaruhi aktivitas kelompok dalam rangka pemuasan dan pencapaian tujuan.

4) Kepemimpinan adalah kegiatan dalam mempengaruhi orang lain untuk bekerja keras dengan penuh kemajuan untuk tujuan kelompok.

5) Kepemimpinan adalah proses mempengaruhi kegiatan-kegiata seseorang atau kelompok dalam usahanya mencapai tujuan di dalam suatu situasi tertentu. ${ }^{32}$

\footnotetext{
${ }^{29}$ Inu Kencana Syafiie, Al-Qur'an dan Ilmu Administrasi (Jakarta: Rineka Cipta, 2000), hlm. 71-72

30 Winardi, Pemimpin dan Kepemimpinan dalam Manajemen (Bandung: Penerbit Alumni, 1983), hlm. 63

${ }^{31}$ Budi Susanto (eds.), Politik Penguasa dan Siasat Pemoeda (Yogyakarta: Kanisius, 1984), hlm. 5

32 Soebagio Atmodiwirio dan Soeranto Totosiswanto, Kepemimpinan Kepala Sekolah (Semarang: Adhi Waskita, 1991), hlm. 5
} 
Dari beberapa pengertian di atas, dapat dinyatakan bahwa bagaimanapun beragamnya rumusan pengertian kepemimpinan yang berkembang tersebut, setidaknya terdapat benang merah yang membuat semua pengertian itu secara esensial mengandung persamaan, yaitu bahwa intinya dalam kepemimpinan itu ada "proses mempengarubi" orang lain agar dapat "berbuat sesuatu" sesuai dengan "tujuan organisasi".

\section{Teori-teori Kepemimpinan Dalam Organisasi}

Pemimpin dan kepemimpinan selalu diperlukan dalam kehidupan manusia. Pemimpin senantiasa muncul sejalan dengan peradaban manusia kapan saja, di mana saja dan dalam keadaan bagaimanapun juga dan bersamaan dengan itu muncul pula berbagai teori tentang kepemimpinan. Kajian dan hasil penelitian tentang kepemimpinan telah mengklasifikasi teori-teori kepemimpinan berdasarkan pendekatan-pendekatan kesifatan, perilaku dan situasional. ${ }^{33}$ Pendekatan-pendekatan kepemimpinan tersebut dijelaskan oleh Pandji Anoraga sebagai berikut:

1) Pendekatan Kepemimpinan menurut Teori Sifat

Menurut teori ini, keberhasilan seorang pemimpin ditentukan oleh situasi, perangai atau ciri yang dimiliki oleh seorang pemimpin. Sifat-sifat tadi berupa sifat fisiologis maupun psikologis, atas dasar pemikiran tersebut timbul anggapan bahwa untuk menjadi seorangpemimpin yang berhasil sangat ditentukan oleh kemampuan pribadi.

2) Pendekatan Kepemimpinan menurut Teori Perilaku

Teori ini berasumsi bahwa perilaku kepemimpinan sangat erat sekali dengan fungsi utama kepemimpinan yaitu menggerakkan orang lain untuk mencapai tujuan. Dalam hal ini sedikitnya ada dua perilaku kepemimpinan, yaitu perilaku yang berorientasi kepada tugas dimana pemimpin memberikan instruksi kepada bawahannya untuk melaksanakan tugasnya sesuai dengan prosedur yang telah ditetapkan, dan perilaku yang berorientasi pada bawahan dimana pemimpin mendelegasikan pengambilan keputusan sendiri secara bebas tapi tetap berada dalam batas-batas yang telah ditetapkan pula.

3) Pendekatan Kepemimpinan menurut Teori Situasional

Dalam teori ini ada dua hal yang perlu diperhatikan, yaitu faktor-faktor yang penting dalam suatu situasi dan gaya kepemimpinan. Pemimpin yang baik menurut teori ini adalah pemimpin yang dapat mengubah gaya kepemimpinan sesuai dengan situasi dan memperlakukan bawahannya sesuai dengan kebutuhannya masing-masing. ${ }^{34}$

33 T. Hani Handoko, Managemen, cet. XV (Yogyakarta: BPFE, 1999), hlm. 295

34 Pandji Anoraga, Psikologi Kepemimpinan (Semarang: Rineka Cipta, 1990), hlm. 8-9 
Selain teori-teori tersebut di atas, Veithzal Riva'i memberikan tiga teori lagi yang merupakan pendekatan kepemimpinan terbaru yaitu sebagai berikut:

1) Teori Kepemimpinan Atribusi

Yaitu teori yang mengemukakan bahwa kepemimpinan semata-mata suatu atribusi yang dibuat orang mengenai individu-individu lain.

2) Teori Kepemimpinan Kharismatik

Teori kepemimpinan kharismatik merupakan suatu perpanjangan dari teori-teori atribusi. Teori ini mengemukakan bahwa para pengikut membuat atribusi (penghubungan) dari kemampuan kepemimpinan yang heroik atau luar biasa bila mereka mengamati perilaku-perilaku tertentu.

3) Teori Kepemimpinan Transaksional dan Transformasional

Kepemimpinan transaksional adalah kepemimpinan yang memandu atau memotivasi pengikut mereka dalam arah tujuan yang ditegaskan dengan memperjelas peran dan tuntutan tugas. Sedangkan dalam kepemimpinan transformasional pemimpin memberikan pertimbangan dan rangsangan intelektual yang diindividualkan dan yang memiliki kharisma. ${ }^{35}$ Dalam kepemimpinan transformasional, pemimpin berusaha untuk merangsang dan membangkitkan motivasi individu atau kelompok yang berada dibawah kepemimpinannya untuk bekerja secara maksimal sehingga menghasilkan sesuatu yang lebih baik dari yang ada sebelumnya. Sementara itu Islam menawarkan sebuah konsep mengenai kepemimpinan. Konsep tersebut menggunakan tiga pendekatan yaitu pendekatan normatif, historis dan teoritis.

Dasar konseptual kepemimpinan Islam secara normatif bersumber pada Al-Qur'an dan Hadits yang terbagi atas empat prinsip pokok yaitu prinsip tanggung jawab dalam organisasi, prinsip etika tauhid, prinsip keadilan dan prinsip kesederhanaan. Secara historis dapat merujuk pada kisah-kisah kepemimpinan para pemimpin Islam terdahulu yang bisa dijadikan teladan. Sedangkan secara teoritis Islam tidak menutup kesempatan mengkomunikasikan ide-ide dan pemikiran dari luar Islam (meskipun sebenarnya konsep kepemimpinan Islam sudah sempurna) selama pemikiran tersebut tidak bertentangan dengan Al-Qur'an dan Sunnah Rasulullah Saw.

\section{Tipe-Tipe Kemimpinan}

Tipe kepemimpinan banyak kita temukan dalam kehidupan sehari-hari kita. Setiap orang mempunyai tipe kepemimpinan yang berbeda-beda, sesuai dengan karakter dasar dan pengalaman kehidupannya. Para ahli filsafat dan

35 Veithzal Rivai, Kepemimpinan dan Perilaku Organisasi (Jakarta: Raja Grafindo Persada, 2003), hlm. 20 
ahli teori sosial mengajukan bermacam-macam tipologi kepemimpinan. Borgadus mengajukan empat tipe kepemimpinan, yaitu: 1) Tipe otokratik, yang berkuasa dalam organisasi yang kuat; 2) Tipe demokratik, yang melambangkan interes dari kelompok; 3) Tipe Eksekutif, yang memperoleh kepemimpinan karena segala hal dapat terlaksana; dan 4) Tipe cermin intelektual, yang mendapatkan kesukaran dalam merebut banyak pengikut. ${ }^{36}$. Tipe ini sedikit berbeda dengan tipe kepemimpinan yang diajukan oleh Getzel dan Guba, yaitu:

1) Nomoteis leadership, berkaitan dengan masalah harapan-harapan dan peranan-peranan yang menentukan.

2) Idiograpic leadership, berhubungan dengan kebutuhan individual dan disposisi anggota yang menentukan dimensi personal dan aktifitas kelompok.

3) Sintetic leadership, yang memertemukan adanya dua sistem yang bertentangan antara dimensi normatif dengan dimensi personal dalam kelompok. ${ }^{37}$

Berdasarkan pandangan para ahli di atas, ada empat pola kepemimpinan pendidikan yang ada dalam kehidupan sosial. ${ }^{38}$ Keempat tipe kepemimpinan tersebut yaitu:

1) Tipe Otokratis; Kepemimpinan otokratis berkeyakinan bahwa dialah yang bertanggung jawab atas segala sesuatu, sehingga maju mundurnya lembaga yang dipimpin tergantung pada pemimpin ini. Sedangkan yang dipimpinnya hanyalah sebagai pelaksana terhadap apa-apa yang telah direncanakan dan diputuskan pemimpin. Dengan sendirinya pemimpin inilah yang bekerja keras penuh ketertiban dan keletihan. Kepemimpinan otokratis ini sering disebut juga sebagai pemimpin dominasi. Hal ini disebabkan adanya kemungkinan bahwa apa yang dilaksanakan oleh pemimpin tidak selalu karena desakan ingin berkuasa atau ingin menonjolkan diri. Tetapi mungkin karena didorong perasaan bertanggung jawab yang terlalu besar.

2) Tipe Laissez Faire (Masa Bodoh); Kepemimpinan laissez faire merupakan kebalikan dari kepemimpinan otokratis. Jika kepemimpinan otokratis selalu mendominasi, maka kepemimpinan semacam ini menyerahkan sepenuhnya pada anggota. Gaya kepemimpinan semacam ini menafsirkan demikrasi dalam arti yang keliru. Demokrasi seolah-olah diartkan sebagai kebebasan bagi tiap anggota untuk mengemukakan dan mempertahankan pendapat dan kebijaksanaan masing-masing. Kepemimpinan laissez faire ini dapat mengakibatkan anggota kelompok bebas dalam menetapkan dan

${ }^{36}$ Mar'at, Pemimpin dan Kepemimpinan, (Jakarta: Ghalia Indonesia, 1983), hlm. 18

${ }^{37}$ Tim Dosen FIP IKIP Malang, Administrasi Pendidikan (Malang: IKIP Perss, 1989), hlm. 265

${ }^{38}$ Ibid, hlm. 266-270 
melaksanakan programnya di satu pihak, dan di pihak yang lain kadang tidak memiliki inisiatif dalam mencapai tujuan dengan sebaik-baiknya. Karena pemimpin semacam ini disebabkan oleh beberapa hal. Diantaranya pemimpin tersebut tidak mampu, tidak tahu cara lain, karena salah mengartikan demokrasi atau karena tidak ada kemauan, malas dan masas bodoh. Pemimpin semacam ini juga sering dinamakan pemimpin tanpa kepemimpinan, karena membiarkan kelompoknya berbuat semaunya sendiri. Semua pekerjaan dan tanggung jawab harus dilaksanakan oleh bawahannya. Pemimpin ini biasanya tidak memiliki kewibawaan dan tidak bisa mengontrol anak buahya, tidak mampu melaksanakan koordinasi kerja dan tidak berdaya sama sekali untuk menciptakan suasana kerja yang kooperatif. Sehingga lembaga yang dipimpinnya menjadi kacau balau, tidak disiplin, dan bekerjanya menurut kemauan sendiri.

3) Tipe Demokratis; Pemimpin demokratis ini selalu menyadari bahwa dirinya merupakan bagian dari kelompoknya. Ia bekerja dengan kelompok dan berusaha untuk membimbing kelompoknya. Berhasil tidaknya pekerjaan ditanggung bersama oleh kelompok. Pemimpin percaya bahwa setiap anggota kelomok memiliki kemampuan untuk mencapai tujuan bersama. Anggota banyak dilibatkan dalam merencanakan dan membuat keputusan-keputusan serta mampu dalam menilai kemajuan pekerjaaannya. Kepemimpinan demokratis ini biasanya berlangsung mantap dengan adanya gejala-gejala diantaranya; organisasi dengan segenap bagian-bagiannya berjalan lancar dan bawahannya menyadari tugasnya serta kewajibannya dengan senang hati dan penuh tanggung jawab. Dalam kepemimpinan demokratis dimungkinkan memunculkan pemimpin yang baru dalam kelompok. Selain itu pemimpin demokratis adalah pemimpin kreatif yang dapat membimbing anggotanya sehingga timbul pemimpin-pemimpin baru sesuai dengan kecakapan dan kemampuan masing-masing.

4) Tipe Pseudo Demokratis; Pemimpin Pseudo demokratis ini sebenarnya bersifat otokratis. Tetapi ia pandai memberikan kesan seolah-olah demokratis. Pemimpin ini berbuat seolah-olah semua rencana rencana program organisasi berasal dari kelompok, padahal semua itu adalah kehendaknya sendiri. Ia selalu menarik perhatian agar disukai orang lain dan berusaha mencari kelemahan orang lain untuk dijadikan senjata agar orang lain segan kepadanya. Dalam rapat-rapat seakan ia memperhatikan saran dan pendapat kelompok walau akhirnya pendapat dan saran tersebut tidak digunakan. Karena sikapnya yang dibuat dibuat ramah, maka anggotanya segan menentangnya dan jika tidak sepaham cenderung untuk diam saja. Pemimpin seperti ini sering disebut dengan pemimpin 
yang memanipulasi demokrasi atau pemimpin dengan kepemimpinan semu.Dalam dunia global ini banyak model-model kepemimpinan yang ditawarkan oleh berbagai pakar untuk menjawab berbagai persoalan kepemimpinan. Model-model tersebut antara lain gaya kepemimpinan berdasarkan kecerdasan emosional. Gaya-gaya kepemimpinan yang didasarkan pada kecerdasan emosional, menurut Riri Satria merujuk pada model Daniel Goleman, McKee, dan Boyatzis, yang terkenal dengan teori primal leadership. Teori primal leadership ini lebih melihat kepemimpinan dari sisi kecerdasan emosional (emotional intelligence). Ini tidaklah mengherankan karena mereka adalah murid dari David Mc Clelland yang merupakan perintis riset di bidang kecerdasan emosional. ${ }^{39}$

\section{Fungsi dan Peran Kepemimpinan dalan Pengembangan Organisasi}

Sebelum mengetahui fungsi kepemimpinan, maka perlu diketahui unsur-unsur penting kepemimpinan. Menurut A.M. Mangunhardjana (2004), ada tiga unsur penting kepemimpinan, yaitu: Tujuan dan cita-cita merupakan unsur yang pertama dan paling pokok, organisasi kerja dan kepribadian dan keahlian. ${ }^{40}$ Hadari Nawawi dalam buku "Kepemimpinan Menurut Islam", mengemukakan bahwa fungsi-fungsi kepemimpinan akan dapat diwujudkan oleh seorang pemimpin, karena pelaksanaannya selalu berlangsung dalam interaksi antar-individu di lingkungan organisasi masing-masing. Dalam interaksi tersebut terdapat dua dimensi, yaitu dimensi kemampuan pemimpin mengarahkan (direction), dan dimensi tingkat dukungan (support) dari anggota organisasi. ${ }^{41}$ Berdasarkan kedua dimensi tersebut, maka secara operasional dapat dibedakan enam fungsi pokok kepemimpinan, yaitu:

1) Fungsi Instruktif ; fungsi ini bersifat komunikasi satu arah. Disini pemimpin adalah pihak yang menentukan apa, bagaimana, kapan dan dimana suatu perintah dilaksanakan. Sedangkan orang yang dipimpin merupakan pihak yang melaksanakan perintah tersebut.

2) Fungsi Konsultatif ; fungsi ini bersifat komunikasi dua arah, karena berlangsung dalam bentuk interaksi antara pemimpin dan anggota organisasinya. Oleh karena itu ketika akan menetapkan berbagai keputusan penting dan strategis pemimpin perlu berkonsultasi dengan anggota organisasi lainnya, demikian pula dalam tahap pelaksanaannya,

39 Riri Satria, Perkembangan Teori Kepemimpinan, Suatu Tinjauan Pustaka (http:// strategy4org.wordpress.com, diakses tanggal 10 Desember 2011)

${ }^{40}$ A.M. Mangunhardjana, SJ., Kepemimpinan (Yogyakarta: Penerbit Kanisius, cet. XX, 2004), hlm. 12-13

${ }^{41}$ Hadari Nawawi, Kepemimpinan menurut Islam (Yogyakarta: Gadjah Mada University Press, 1993), hlm. 142 
sehingga diharapkan muncul feed back (umpan balik) demi perbaikanperbaikan keputusan tersebut.

3) Fungsi Partisipasi; Dalam fungsi partisipasi ini seorang pemimpin harus berusaha mengaktifkan setiap anggota organisasinya untuk ikut berpartisipasi baik dalam pengambilan keputusan maupun dalam pelaksanaan keputusan tersebut. Di sini pemimpin mendorong setiap anggota agar aktif dalam melaksanakan tugas pokoknya sesuai dengan posisi/jabatan dan wewenangnya masing-masing.

4) Fungsi Delegasi; setiap manusia memiliki keterbatasan, demikian pula dengan pemimpin, pemimpin tidak mungkin bekerja sendiri dalam mewujudkan tugas-tugas pokok organisasinya, untuk itu dalam hal ini diperlukan faktor delegasi yaitu dengan melimpahkan sebagian wewenangnya kepada para staf yang membantunya.

5) Fungsi Pengendalian; fungsi pengendalian ini dilaksanakan oleh pemimpin melalui kegiatan kontrol atau pengawasan, bimbingan kerja, termasuk juga memberikan penjelasan dan contoh dalam bekeja, latihan di lingkungan organisasi lain dan sebagainya.

6) Fungsi Keteladanan; pemimpin adalah tokoh sentral yang selalu menjadi pusat perhatian dalam sebuah organisasi. Oleh karena itu seseorang yang dipilih dan diangkat menjadi pemimpin, selain harus menjalankan perannya sebagai pemimpin, juga harus bisa menjadi seorang figur yang bisa menjadi teladan bagi bawahannya. ${ }^{42}$

Mengenai peran seorang pemimpin dalam organisasi, Sondang P. Siagian mengemukakan 5 (lima) peran penting seorang pemimpin, yaitu sebagai berikut:

1) Sebagai pemegang kemudi organisasi, dalam hal ini seorang pemimpin harus cekatan, cermat, dan penuh perhitungan dalam membawa organisasinya ke tempat tujuan yang telah ditetapkan sebelumnya.

2) Sebagai katalisator, sebagai katalisator pemimpin harus mampu meningkatkan laju jalannya organisasi.

3) Sebagai integrator (penyatu), peran integrator diperlukan untuk menyatakan dan merekatkan hubungan antara sekian banyak bagian atau komponen yang ada di lingkungan organisasi tersebut.

4) Sebagai Bapak, di sini peran pemimpin tidak hanya terbatas sebagai seorang atasan tetapi juga sebagai pengayom dan tempat bertanya, selayaknya seorang bapak.

5) Sebagai Pendidik, pendidikan dapat berlangsung kapanpun dimanapun dan dengan cara apapun. Sehingga pemimpin dapat memberikan pendidikan

${ }^{42}$ Ibid, hlm. 143-51 
dengan cara memberi contoh yang baik kepada bawahannya, baik itu lewat ucapan maupun Perilakunya. ${ }^{43}$

Mintzberg, sebagaimana dikutip oleh Miftah Thaha membagi tiga peran utama yang harus dimainkan oleh setiap pemimpin dimanapun letak hierarkinya. Peran ini adalah: ${ }^{44}$

1) Peranan hubungan antar pribadi (Interpersonal role) Peranan ini meliputi:

a) Peranan sebagai figurehead. Peranan ini leboih bersifat simbolis, karena merupakan suatu peranan yang dilakukan u ntuk mewakili lembaga yang dipimpimnya di dalam setiap kesempatan dan persoalan yang timbul secara formal.

b) Peranan sebagai pemimpin (leader). Dalam peran ini berarti seorang pemimpin harus melakukan fungsi sebagai motivator, pengembang, dan pengendali yang dilakukan dalam hubungan interpersonal dengan yang dipimpin.

c) Peranan sebagai pejabat perantara (liaison), di sini pemimpin melakukan peranan yang berinteraksi dengan teman sejawat, staf, dan orang lain yang berada di luar organisasinya untuk mendapat informasi. Ini menandakan adanya hubungan pertukaran (exchange relationship) guna suatu perubahan yang dimungkinkan dalam upaya pengembangan lembaga.

2) Peranan yang berhubungan dengan informasi (Information role) Peranan ini mencakup:

a) Sebagai monitor. Peranan ini mengidentifikasikan seorang pemimpin sebagai penerima dan pengumpul informasi, agar ia mampu mengembangkan suatu pengertian yang baik dari lembaga yang dipimpinnya, dan merupakan pemahaman yang komlit tentang lingkunagnnya. Pemimpin mencari informasi agar ia mampu untuk mengidentifikasikan permasalahan kelembagaan dalam pendidikan yang muncul serta mencari celah penyelesaian dan pengembangan. Untuk membangun pengetahuan tentang lingkunagna kelembagaan, menjadi tahu kapan informasi itu harus diberikan kepada bawahan dan segenap jajaran lembaga.

b) Sebagai dessiminator. Peranan ini menangani proses transmisi dari informasi-informasi ke dalam organisasi yang dipimpinnya. Seorang pemimpin menyampaikan informasi daro luar ke dalam organisasi dan informasi dari bawahan ke bawahan.

c) Sebagai juru bicara (spokeman). Peranan ini dilakukan pemimpin dalam rangka publikasi keluar organisasi.

\footnotetext{
${ }^{43}$ Sondang P. Siagian, Organisasi Kepemimpinan dan Perilaku Administrasi, (Jakarta: Haji Masagung, 1991), hlm. 21-22

${ }^{44}$ Miftah Thaha, Kepemimpinan dalam Managemen (Jakarta: Rajawali Press, 1995), hlm. 13-16
} 
3) Peranan Pembuat Keputusan (Decision role)

Peranan ini biasanya merupalkan peran yang rumit, karena menyangkut ketegasan lembaga dalam suatu permasalahan. Peranan ini membuat pemimpin harus terlibat dalam suatu proses pembuatan strattegi dalam organisasi yang dipimpinnya. Proses pembuatan strategi ini secara sederhana dinamakan suatu proses yang menjadikan keputusan organisasi secara signifikan dan berhubungan. Peranan pemimpin yang dikelompokkan dalam pembuat keputusan, yaitu:

a) Peranan sebagai interpreneur, dalam peran ini pemimpin dalam lembaga pendidikan betindak sebagai pemrakasa berbagai kebijakan lembaga. Peran ini berawal dari aktifitas pencermatan dan pemahaman terhadaop persoalan-persoalan lembaga.

b) Peranan sebagai penghalau gangguan. Peran ini membawa pemimpin untuk bertanggung jawab terhadap organisasi ketika organisasi terancam bahaya. Ini menuntut ketegasan sikap pemimpin untuk mengambil langkah-langkah taktis sebagai tindak penyelamatan.

c) Peranan sebagai negoisator. Peran ini terkait dengan hubungan antar lembaga yang diupayakan kesemuanya mengarah kepada pengembangan lembaga.

Dari peran dan syarat ideal seorang pemimpin dalam lembaga pendidikan di atas, ada dua kapasitas pokok sebagai main point yang harus dimiliki seorang pemimpin, yaitu: managerial skill dan technical skill. Namun demikian sukses atau tidaknya seorang pemimpin dalam melaksanakan tugas kepemimpinannya, tidak hanya ditentukan oleh tingkat ketrampilan teknis (technical skill) yang dimiliki, akan tetapi lebih banyak ditentukan oleh keahliannya menggerakkan orang lain untuk bekerja dengan baik (managerial skill). Dalam hal ini perlu dipahami bahwa seorang pemimpin adalah seorang yang tidak melaksanakan sendiri tindakan-tindakan yang bersifat operasional. Tetapi mengambil keputusan, kebijakan dan menggerakkan orang lain untuk melaksanakan keputusan yang telah diambil sesuai dengan kebijaksanaan yang telah digariskan.

Penjelasan di atas menggambarkan bahwa figur ideal dari kepemimpinan pendidikan ini terkait dengan kualitas kepemimpinan yang dimiliki seorang pemimpin. Kepemilikan terhadap syarat dan peran yang dapat mewakili upaya pengembangan organisasi, akan menentukan ideal tidaknya seorang pemimpin dalam mengelola dan mengatur jalannya roda suatu organisai, baik organisasi sosial, politik, pendidikan, maupun organisasi perusahaan dan semacamnya.

\section{Konsep Khalifatullah Sebagai Model Ideal Kepemimpinan Organisasi yang Bermutu}




\section{Konsep Khalifatullah sebagai Konsep Kepemimpinan Organisasi}

Mungutip pendapatnya Muhammad Baqir Al-Shadr, M. Quraish Shihab mengemukakan bahwa kekhalifahan mempunyai tiga unsur yang saling berkaitan. Kemudian, ditambahkannya unsur keempat yang berada di luar, namun sangat menentukan arti kekhalifahan dalam pandangan AlQuran. Ketiga unsur pertama adalah:

1) Manusia, yang dalam hal ini dinamai khalifah.

2) Alam raya, yang ditunjuk oleh ayat Al-Baqarah ayat 22 sebagai ardh.

3) Hubungan antara manusia dengan alam dan segala isinya, termasuk dengan manusia.

Sedangkan unsur keempat yang berada di luar adalah yang memberi penugasan, yakni Allah SWT. Dialah yang memberi penugasan itu dan dengan demikian yang ditugasi harus memperhatikan kehendak yang menugasinya. Dengan demikian, konsep khalifatullah itu menuntut adanya interaksi antara manusia dengan sesamanya dan manusia dengan alam sesuai dengan petunjuk-petunjuk Ilahi yang tertera dalam wahyu-wahyu-Nya. Semua itu harus ditemukan kandungannya oleh manusia sambil memperhatikan perkembangan dan situasi lingkungannya.

Inilah prinsip pokok yang merupakan landasan interaksi antar sesama manusia dan keharmonisan hubungan itu pulalah yang menjadi tujuan dari segala etika agama. Keharmonisan hubungan inilah yang menghasilkan etika agama yang tidak mengenal prinsip "Anda boleh melakukan apa saja selama tidak. melanggar hak orang lain", tetapi etika yang memperkenalkan memperkenalkan "Mereka mendahulukan pihak lain atas diri mereka walaupun mereka sendiri dalam kebutuhan". Inilah sifat dasar kepemimpinan yang ideal yang dikehendaki oleh Allah Swt.

Keharmonisan hubungan dalam membangun relasi sosial baik dalam lingkungan masyarakat ataupun dalam lingkungan organisasi akan melahirkan kemajuan dan perkembangan masyarakat. Perkembangan inilah yang merupakan arah yang dituju oleh masyarakat yang Islami. Keharmonisan tidak mungkin tercipta kecuali jika dilandasi oleh rasa aman. Karena itu pula, setiap aktivitas istikblaf (pembangunan) baru dapat dinilai sesuai dengan etika agama apabila rasa aman dan sejahtera menghiasi setiap anggota masyarakat ataupun anggota organisasi. Dengan kata lain, pembangunan yang dihiasi oleh etika agama adalah yang mengantar manusia menjadi lebih bebas dari penderitaan dan rasa takut. Kalau hal ini dikaitkan dengan kisah kejadian manusia, maka dapat pula dikatakan bahwa keberhasilan pembangunan dalam pandangan agama adalah pada saat manusia berhasil mewujudkan bayang-bayang surga di persada bumi ini. 
Mengutip pendapatnya Prof. Mubyarto, M. Quraish Shihab mengemukakan lima hal pokok untuk mencapai rasa aman: ${ }^{45}$

1. Kebutuhan dasar setiap masyarakat harus terpenuhi dan ia harus bebas dari ancaman dan bahaya pemerkosaan.

2. Manusia terjamin dalam mencari nafkah, tanpa harus keterlaluan menghabiskan tenaganya.

3. Manusia bebas untuk memilih bagaimana mewujudkan hidupnya sesuai dengan cita-citanya.

4. Ada kemungkinan untuk mengembangkan bakat-bakat dan kemampuannya.

5. Partisipasi dalam kehidupan sosial politik, sehingga seseorang tidak semata-mata menjadi objek penentuan orang lain.

Lebih lanjut, M. Quraish Shihab memetakan karakteristik khalifatullah dengan menganalisis tafsir milik Al-Tabrasi dikemukakan didalamnya bahwa kata Imam (pemimpin) mempunyai makna yang sama dengan khalifah. Hanya kata Imam digunakan untuk keteladanan, karena ia diambil dari kata yang mengandung arti depan, yang berbeda dengan khalifah yang terambil dari kata "belakang" atau "pengganti".

Dengan demikian, makna Khalifatullah merupakan wakil atau pengganti Tuhan di muka bumi, yang menuntu seseorang memiliki kompetensi kepemimpinan sebagai alat untuk melaksanakan tugasnya mengelola bumi. Demikian juga dalam kepemimpinan organisasi (apapun bentuk organisasinya), seseorang harus memiliki dasar kekhalifahansebagaik bekal untuk menggerakkan masyarakat untuk mencapai tujuan manusia atau tujuan organisasi. Memperhatikan masalah kepemimpinan dan khalifatullah, M. Quraish Shihab menganalisa dalam Al-Quran, dan ada tiga kata yang menjadi rujukan makna kedua istilah tersebut:

\section{a. Khalifah}

Sebagaimana diuraikan di depan Khalifah, arti dasarnya adalah yang di belakang atau pengganti. Fungsinya memberikan dorongan kepada yang ada di depan. Kata Khalifah di dalam Al-Quran hanya dua kali disebut. Pertama, ketika Tuhan memberitahukan kepada malaikat tentang rencananya untuk mengutus manusia sebagai khalifah di muka bumi. Surat Al-Baqarah, Allah berfirman "Ingatlah ketika Tuhanmu berfirman kepada para Malaikat: "Sesunggubnya Aku hendak menjadikan seorang khalifah di muka bumi." .(QS. 2:30). Kedua, di dalam Surat Ash-Shaad, "Hai Daud, sesunggubnya Kami menjadikan kamu khalifah (penguasa) di muka bumi”. (QS. 38:26).

Lihatlah perbedaan dalam kedua surat di atas. Allah menggunakan kata "Aku" dalam merencanakan adanya khalifah/pemimpin di muka bumi,

${ }^{45}$ M. Quraish Shihab, Membumikan Al-Quran hal. 162 
tapi pada QS. (2:30), digunakan kata "Kami" ketika mengangkat seorang khalifah/pemimpin pada QS. (38:26). Menurut M. Quraish Shihab, apabila Allah menggunakan kata "Kami" maka menunjukkan bahwa ada keterlibatan peran makhluk selain Allah sendiri, berbeda halnya jika Allah menggunakan kata "Aku" maka itu hanya Allah saja yang berperan. Ketika Nabi Daud diangkat menjadi pemimpin maka ketika itu, Allah dan manusia di lingkungan Nabi Daud telah mengangkat Nabi Daud sebagai pemimpin buat umat/rakyatnya.

b. Imam

Imam mempunyai arti dasarnya adalah yang dituju, yang diteladani. Oleh karena itu, Ummi (Ibu) mempunyai makna tempat yang dituju oleh anak-anaknya. Begitu juga dengan arti Imam Shalat, adalah orang yang dituju oleh para makmumnya ketika sholat berjamaah.

Di dalam Al-Qur'an, kata Imam terdapat dalam surat Al-Baqarah : "Dan (ingatlab), ketika Ibrabim diuji Tuhannya dengan beberapa kalimat (perintah dan larangan), lalu Ibrabim menunaikannya". Allah berfirman: "Sesungguhnya Aku akan menjadikanmu imam (pemimpin) bagi selurub manusia". Ibrahim berkata: "(Dan saya mohon juga) dari keturunanku". Allah berfirman: "JanjiKu (ini) tidak mengenai orang yang zalim". QS. (2:124).

Ketika Ibrahim dijadikan imam (pemimpin) oleh Allah, Nabi Ibrahim meminta agar keturunan-keturunannya pun diangkat menjadi imam. Tapi dijawab oleh Allah bahwa perjanjian kontrak antara Allah dan Ibrahim tidak berlaku bagi orang-orang yang berlaku aniaya. Sebuah konsep kepemimpinan yang dicontohkan oleh Allah, bahwa pakta integritas menjadi penting dalam menentukan layak tidaknya seseorang menjadi pemimpin suatu kelompok masyarakat (suatu organisasi).

c. Ulil Amri : Pemerintah (Menyuruh atau Disuruh)

Amir dapat mengandung arti subyek yaitu menyuruh dan bisa mempunyai arti obyek yaitu yang disuruh. Seorang pemimpin adalah seorang yang mampu menyuruh dengan baik namun juga bersedia dengan rela disuruh oleh rakyat yang dipimpinnya dan juga Allah Swt. yang telah memberinya amanah. Seorang pemimpin hendaknya semaksimal mungkin dapat memenuhi kebutuhan rakyatnya, melayani rakyatnya dan sebagainya. Jika dia tidak bersedia disuruh oleh rakyat maka dia tidak layak diangkat menjadi pemimpin.

Ketiga nama atau sebutan untuk pemimpin yaitu khalifah, imam dan ulil amri adalah menunjukkan bahwa pemimpin memiliki fungsi ketiga hal utama:

1) Pemimpin sebagai khalifah, yaitu yang berada di belakang, fungsinya memberikan dorongan, fasilitas, semangat dan sebagainya;

2) Pemimpin sebagai imam, yaitu yang berada di depan, fungsinya sebagai teladan atau imam; dan 
3) Pemimpin sebagai amir, yang bersedia untuk memerintah dan diperintah.

Oleh karena itu, seorang pemimpin selalu dekat dengan rakyatnya, selalu berada di tengah-tengah mereka karena seorang pemimpin dalam memerintah tidaklah efektif jika berada di kejauhan dari rakyatnya, dan begitu juga rakyat tidak mungkin bisa memberikan permintaan, masukan dan perintah kepada pemimpinnya jika pemimpinnya tidak berada di depannya.

Dengan demikian, konsep khalifatullah itu sesungguhnya adalah konsep kepemimpinan (leadership) yang dapat dicirikan sebagai berikut: a) Orang yang berada di depan menjadi menjadi imam (teladan); b) Orang yang berada di belakang menjadi khalifah (pendorong); c) Orang yang berada di tengah menjadi amir (ikut merasakan); d) Orang yang pandai memerintah; e) Orang yang rela diperintah oleh masyarakat; f) Orang yang tabah; g) Orang yang mengabdi; dan h) Orang yang pandai mengantar dan menuntun rakyatnya kepada yang baik.

Dalam literatur pendidikan Indonesia kita mengenal imam (teladan), khalifah (pendorong), amir (ikut merasakan) dengan semboyan yang diciptakan oleh Ki Hajar Dewantara, berhubungan dengan pemimpin, yaitu:Ing ngarso sung tulodo (di depan menjadi teladan), Ing madyo mangun karso (di tengah-tengah membangun karya (karir, moral, pembangunan, material, dan lainnya), dan Tut Wuri Handayani (di belakang memberi dorongan dan support).

Konsep kepemimpinan berada di depan dengan menjadi teladan atau contoh, di tengah-tengah dengan cara ikut bekerja dan merasakan bersamasama kebutuhan organisasi dan para anggotanya, dan berada di belakang dengan cara memberikan motivasi, menggerakkan dan mengarahkan inilah yang tepat untuk diterapkan dalam organisasi modern. Hal ini tentu akan mempermudah pencapaian tujuan suatu organisasi.

Konsep di atas, tentu sangat relevan dengan fungsi pemimpinan (leading) dalam manajemen yang dapat disebut pula dengan bermacammacam nama seperti mengarahkan (directing), menggerakkan (actuating), memotivasi atau mendorong (motivating), dan lain semacamnya. Pemimpinan menurut Stoner menunjukkan bagaimana para manajer mengarahkan dan mempengaruhi bawahannya, menggunakan orang lain untuk melaksanakan tugas tertentu, dengan menciptakan suasana yang tepat membantu bawahan bekerja sebaik mungkin ${ }^{46}$.

\section{Makna dan Karakteristik Khalifatullah sebagai Model Ideal Kepemimpinan Organisasi yang Bermutu}

\footnotetext{
${ }^{46}$ Stoner, James A.F. Manajemen. (edisi revisi) (Terjemahan Alfonsus Sirait) (New York: PrenticeHall International Inc, 1996), hal. 8 (Buku asli diterbitkan tabun 1982).
} 
Kedudukan manusia sebagai khalifatullah meniscayakan manusia untuk mempertanggungjawabkan segala aktifitasnya kepada yang digantikan, yang diwakili dan yang memberikan mandataris, yaitu Allah Swt. Karena itu manusia sepanjang hidupnya harus mengimplementasikan dirinya sebagai makhluk yang bertugas menciptakan keharmonisan dalam kehidupan sesuai dengan keinginan Allah. Manusia dipilih sebagai kbalifatullah, karena kelebihan yang dianugerahkan Allah kepada manusia berupa ilmu pengetahuan, yang tidak diberikan kepada makhluk Allah yang lain termasuk malaikat. Karena dengan ilmu ini manusia mampu menjalankan fungsi dan perannya sebagai pemimpin kehidupan di muka bumi.

Kedudukan khalifatullah (pemimpin) yang melekat otomatis kepada manusia membuat semua manusia mendapat predikat yang sama sebagai khalifah. Namun hanya kualifikasinya saja yang berbeda. Kedudukan ini pula yang menjadi modal awal (potensi) manusia dalam kepemimpinan. Kepemimpinan yang baik, tentu kepemimpinan yang sejalur visi dan orientasinya sebagai khalifatullah. Visi inilah yang menjadi dasar penilaian apakah kepemimpinan seseorang dalam suatu organisasi untuk mencerminkan khalifahannya atau tidak.

Oleh karena itu, peran dan fungsi kekhalifahan (kepemimpinan) harus tampak dalam aktivitas kepemimpinan seseorang dalam suatu organisasi.Secara lengkap dapat kita gabungkan makna kekhalifahan manusia ini dengan peran dan fungsi kepemimpinan, yaitu sebagai berikut:

1) Sebagai pemegang kemudi organisasi

Dalam pengembangan pendidikan Islam, kepemimpinan harus cekatan, cermat, dan penuh perhitungan dalam membawa organisasinya sejalur dengan tujuan hidup kemanusiaan.

2) Sebagai katalisator

Kepemimpinan harus menjadi katalisator antara yang duniawi dan ukhrowi. Membawa hal yang bersifat duniawi saja menjadi bernilai ukhrowi. Demikian pula menghantarkan yang ukhrowi menjadi lebih membumi.

3) Sebagai integrator (penyatu)

Peran integrator diperlukan untuk menyatukan dan merekatkan hubungan dengan menjaga silaturrahmi antara sekian banyak bagian atau komponen yang ada di lingkungan organisasi.

4) Sebagai pendidik

Pendidikan dapat berlangsung kapanpun dimanapun dan dengan cara apapun. Sehingga pemimpin dapat memberikan pendidikan dengan cara memberi contoh yang baik kepada bawahannya, baik itu lewat ucapan 
maupun perilakunya. Dengan begitu dia telah melakukan kegiatan mendidik, meskipun dengan cara yang sederhana sekalipun. ${ }^{47}$

M. Quraish Shihab mengharuskan khalifatullah memiliki karakter sebagai manusia secara pribadi maupun kelompok, mampu menjalankan fungsinya sebagai hamba Allah, guna membangun dunia sesuai dengan konsep yang ditetapkan Allah. Sehingga khalifatullah harus memiliki empat sisi karakter yang saling terkait. Keempat sisi tersebut adalah: a) Memenuhi tugas yang diberikan Allah; b) Menerima tugas tersebut dan melaksanakannya dalam kehiduan perorangan maupun kelompok (organisasi); c) Memelihara serta mengelola lingkungan hidup untuk kemanfaatan bersama; dan d) Menjadikan tugas-tugas khalifah sebagai pedoman pelaksanaannya.

Karakter dan sifat seperti inilah yang harus menjiwai dalam kepemimpinan suatu organisasi. Karakter dan sifat khalifatullah tersebut dalam kepemimpinan organisasi ruang lingkupnya adalah sebagai berikut:

1) Dimensi kecerdasan emosional. Kepemimpinan pada dimensi ini adalah pemimpin yang berhasil adalah mereka yang sanggup mengendalikan atau memainkan emosinya, atau memiliki kecerdasan emosional yang tinggi.

2) Dimensi nyali. Inti dari teori kepemimpinan pada dimensi ini adalah pemimpin yang berhasil adalah mereka yang memiliki nyali atau keberanian untuk membuat keputusan dan melaksanakannya demi mencapai sasaran bersama.

3) Dimensi kematangan karakter. Inti dari teori kepemimpinan pada dimensi ini adalah pemimpin yang berhasil adalah mereka yang tidak menonjolkan diri, sangat mengutamakan kepentingan atau kemajuan bersama dari pada popularitas pribadinya.

4) Dimensi kompetensi. Inti dari teori kepemimpinan pada dimensi ini adalah pemimpin yang berhasil adalah mereka yang memiliki kompetensi tertentu, terutama yang berkaitan dengan soft skills.

5) Dimensi prinsip. Inti dari teori kepemimpinan pada dimensi ini adalah pemimpin yang berhasil adalah mereka yang memiliki prinsip yang kuat dalam memimpin, tidak terjebak dalam keraguan, dan selalu berpegang teguh pada prinsip tersebut. Prinsip ini adalah keyakinan pada fungsi kekhalifahannya ${ }^{48}$, yang memang telah diberikan amanah yang mulia oleh Allah untuk menjadi pemimpin dalam kehidupan sosial.

\section{Penutup}

Berdasarkan pada pembahasan di atas, maka dapat disimpulkan bahwa:

\footnotetext{
${ }^{47}$ Lihat Sondang P. Siagian, Organisasi Kepemimpinan .................... hlm. 21 - 22

48 Riri Satria, Perkembangan Teori Kepemimpinan: Suatu Tinjauan Pustaka, (http:// strategy4org.wordpress.com, Diakses Tanggal 10 Desember 2011)
} 
1. Konsep khalifatullah mengandung tiga makna kepemimpinan yang dapat diterapkan dalam kepemimpinan organisasi, yaitu: a) pemimpin yaitu khalifah, pemimpin yang selalu berada di belakang, yang fungsinya memberikan dorongan, fasilitas, semangat, menggerakkan, mengarahkan, dan sebagainya; b) pemimpin sebagai imam, yaitu yang berada di depan, fungsinya sebagai teladan atau imam; dan c) pemimpin sebagai amir, yang bersedia untuk memerintah dan diperintah.

2. Peran dan fungsi kekhalifahan (kepemimpinan) seseorang harus tampak dalam aktivitas kepemimpinan suatu organisasi, dengan cara menunjukkan peran dan fungsinya sebagai pemimpin, yang dapat menjadi: a) pemegang kemudi organisasi, b) katalisator; c) integrator (penyatu), dan d) sebagai pendidik.

3. Konsep khalifatullah sebagai model kepemimpinan organisasi harus memiliki empat sisi karakter yang saling terkait, yaitu bahwa kepemimpinan itu merupakan; a) tugas yang diberikan Allah, b) tugas tersebut harus dipraktekkan dalam kehiduan perorangan maupun kelompok (organisasi), c) memelihara serta mengelola lingkungan hidup untuk kemanfaatan bersama seluruh umat manusia, dan d) menjadikan tugas-tugas khalifah sebagai pedoman pelaksanaannya. Keempat karakter ini kemudian menuntut manusia sebagai khalifah (pemimpin) untuk memiliki beberapa dimensi fundamental yang dibutuhkan oleh pemimpin ideal suatu organisasi, yaitu dimensi kecerdasan emosional, dimensi nyali, dimensi kematangan karakter, dimensi kompetensi, dan dimensi prinsipberupa keyakinan yang kokoh pada fungsi kekhalifahan-nya.

\section{DAFTAR PUSTAKA}

A.M. Mangunhardjana, SJ., , Kepemimpinan, Yogyakarta: Penerbit Kanisius. 2004 Abdullah, Abdur Rahman Shalih, Landasan dan Tujuan Pendidikan menurut AlQuran serta Implementasinya, Bandung: Diponegoro. 1991

Ahmad Warson Munawwir, (tt.) Al munawnir, Kamus Arab - Indonesia, Yogyakarta: PP. Krapyak.

Ali Yafie, (1997), Teologi Sosial: Telaah Kritis Persoalan Agama dan Kemanusiaan, Yogyakarta: LKPSM.

Budi Susanto (eds.), Politik Penguasa dan Siasat Pemoeda, Yogyakarta: Kanisius. 1984

Bush, T. \& Coleman, M. Leadership and strategic management in education. London: Paul Chapman Publisihing Ltd. 2000

Covey, Stephen R., The $8^{\text {th }}$ Habit from Effectiveness to Greaness, London: Simon \& Schuster Uk Ltd. 1989 
Enco Mulyasa, Manajemen Berbasis Sekolah: Konsep, Strategi, dan Implementasi, Bandung: PT Remaja Rosdakarya. 2002

Endang Saifuddin Anshari, Wawasan Islam, Pokok-Pokok Pikiran tentang Islam dan Umatnya, Bandung: Pustaka. 1983

Hadari Nawawi, Kepemimpinan menurut Islam, Yogyakarta: Gadjah Mada University Press. 1993

Hart, Michael H, Seratus Tokoh yang Paling Berpengarub dalam Sejarah. Jakarta: Pustaka Jaya. 1994

Hasan Langgulung, Manusia dan Pendidikan, Suatu Analisa Psikologi dan Pendidikan, Jakarta: Pustaka Al Husna. 1989

Husaini Usman, (2006), Manajemen, Teori, Praktik, dan Riset Pendidikan, Jakarta: PT Bumi Aksara.

Inu Kencana Syafiie, Al-Qur'an dan Ilmu Administrasi, Jakarta: Rineka Cipta. 2000 Jalaludin, Teologi Pendidikan, Jakarta: Raja Grafindo Persada. 2000

Lunenburg, F.C. \& Ornstein, A.C. Educational administration concepts and practices. $\left(3^{\text {rd }}\right.$.ed.), Belmont: Wadsworth Thomsong Learning. 2000

M. Quraish Shihab, Membumikan Al- Quran, Fungsi dan Peran Wabyu dalam Kehidupan Masyarakat, cet. XXII, Bandung: Mizan. 2001

M. Rasyid Ridha, (tt.), Tafsir Al-Manar, Libanon: Beirut.

Machasin, Menyelami Kebebasan Manusia, Yogyakarta: INHIS-Pustaka Pelajar. 1996

Mar'at, Pemimpin dan Kepemimpinan, Jakarta: Ghalia Indonesia. 1983

Miftah Thaha, Kepemimpinan dalam Managemen, Jakarta: Rajawali Press. 1995

Muhammad Syafii Antonio, Teladan Sukses dalam Hidup dan Bisnis: Muhammad SAW, The Super Leader, Super Manager, Jakarta: Tazkia Multimedia \& ProLM Centre. 2007

Musthofa Al-Maraghi, Tafsir Al-Maraghi (teri.), Semarang: Toha Putra.1985

Nurcholis Madjid, Islam, Doktrin dan Peradaban, Jakarta: Paramadina.1992

Pandji Anoraga, Psikologi Kepemimpinan, Semarang: Rineka Cipta. 1990

Sadler, P. Leadership. (The fast-track MBA series). London: Kogan Page Limited. 1997

Soebagio Atmodiwirio dan Soeranto Totosiswanto, Kepemimpinan Kepala Sekolah, Semarang: Adhi Waskita. 1991

Sondang P. Siagian, Organisasi Kepemimpinan dan Perilaku Administrasi, Jakarta: Haji Masagung. 2011

Stoner, James A.F. Manajemen. (edisi revisi) (Terjemahan Alfonsus Sirait) New York: Prentice-Hall International Inc. (Buku asli diterbitkan tahun 1982). 1996

T. Hani Handoko, Managemen, cet. 17, Yogyakarta: BPFE. 2011

Tedi Priatna, Reaktualisasi Paradigma Pendidikan Islam, Bandung: Pustaka Bani Quraisy. 2004 
Tim Dosen FIP IKIP Malang, Administrasi Pendidikan, Malang: IKIP Perss. 1989

Tina Yulistina, Kepemimpinan Model Nabi, dalam(www.pikiran-rakyat.com), diakses 10 Desember 2010).

Veithzal Rivai, Kepemimpinan dan Perilaku Organisasi, Jakarta: Raja Grafindo Persada. 2003

Wahjosumidjo, Kepemimpinan Kepala Sekolah, Jakarta: PT Rajagrafika Persada. 2002

Winardi, Pemimpin dan Kepemimpinan dalam Manajemen, Bandung: Penerbit Alumni.1983 